\title{
The Russian Morphosyntax of Loanwords in the Automotive Magazine "Мотоэксперт" (Motoekspert) December 2017 Edition
}

\author{
Yusuf Firdaus Ramadhan \\ Russian Studies, Faculty of Humanities, Universitas \\ Indonesia \\ Depok, Indonesia \\ yusuf.firdaus@ui.ac.id
}

\author{
Nia Kurnia Sofiah \\ Russian Studies, Faculty of Humanities, Universitas \\ Indonesia \\ Depok, Indonesia \\ niadee@gmail.com
}

\author{
Njaju Jenny Malik \\ Russian Studies, Faculty of Humanities, Universitas Indonesia \\ Depok, Indonesia \\ je_lik@yahoo.com
}

\begin{abstract}
Loanwords have become a common phenomenon in many languages. As a language develops, loanwords can be found both in written and spoken texts. Loanwords can be found in print media such as magazines. The data of this research is Motoekspert, a popular automotive magazine in Russia, and taken specifically from the December 2017 edition. This research used the descriptive-analytical method in light of two theories. The first is about word borrowing, including Haugen (1950) on the definition of word borrowing, Krysin (2000) on the causes of borrowing, and Rozental' (2001) on the characteristics of borrowed nouns. The second includes Savko (2004) on the criteria of Russian nouns, declension, and function of nouns in sentences and Rozental' (2005) on compound nouns. The results show that loanwords used in the magazine are treated as Russian nouns. It means that all criteria of the Russian nouns (gender, number, case) are also applied for the loanwords. The compound nouns are also found.
\end{abstract}

Keywords-loandwords; automotive; Russian language; morphosyntax; compound nouns

\section{INTRODUCTION}

The definition and causes of word borrowing have been discussed by Haugen (1950) and Krysin (2000). Word borrowing is defined by Haugen as:

"... the attempted reproduction in one language of patterns previously found in another" (Haugen, 1950, p. 212).

The words resulted from word borrowing from other languages are adapted to the recipient language. This is in line with Rozental's statement that in the Russian language, loanwords from foreign languages follow the morphosyntax of the Russian language such as declension and conjugation (Rozental', 2001, pp. 67-68).
According to Krysin (2000, pp. 146-147), the causes of word borrowing include: (1) naming or titling, (2) referring to similar qualities but with different meanings, (3) assigning specific meanings in particular contexts for particular purposes, (4) euphemism, (5) tendency to use a single word if the object is a single unity, (6) terminology in certain thematic contexts, \& (7) socio-psychological factors-speaking in a foreign language is considered prestigious

The focus of this research is how loan nouns used in automotive contexts are adapted into the Russian language. Therefore, the purpose of this research is to describe the adaptation of loan nouns in automotive contexts in the Russian language. The data of this research were obtained from the Russian magazine Motoekspert December 2017 edition. This magazine was chosen because it specifically discusses automotive topics.

\section{LITERATURE REVIEW}

This research examines loanwords in the Russian language found in the Motoekspert magazine. According to Boentarto et. al. (in Darheni, 2009, p. 649), automotive is all about motor vehicles and automobile. Vehicles and machines/engines in this context are cars and motorcycles as well as all about them.

Sentence discussion includes morphology and syntax, which are part of the grammatical subsystem. Morphology focuses on the internal structure of words, while syntax focuses on the structure of language units larger than words, including phrases and sentences (Sihombing \& Kentjono in Kushartanti, Yuwono and Lauder, 2009, p. 123).

Word class in the Russian language according to Savko (2005, pp. 174-175) is divided into three, namely independent word class, auxiliary word class, and interjections. The independent word class is further divided into six, namely 
nouns, adjectives, numbers, pronouns, verbs, and adverbs. This research focuses only on nouns because most loanwords are nouns (Hudson, 1969, p. 482).

The noun morphology of the Russian language according to Savko (2005, pp. 175-186) comprises pod (rod) 'gender', число (cislo) 'number', падеж (padeź) 'case', and одушевленныеl неодушевленные (oduševlennye/ neoduševlennye) 'animate/inanimate'. In this research, all loanwords in the automotive context are inanimate nouns.

As for gender, there are three types of nouns, мужской род (muźskoj rod) 'masculine', женский род (źenskij rod) 'feminine', and средный род (srednyj rod) 'neutral'. The three gender types have different markers. In the singular nominative case, masculine nouns end in consonants $-\varnothing,-\check{u}(-$ $\mathrm{j})$, or $-b(-')$, feminine nouns end in $-a / g(-\mathrm{a} / \mathrm{ja})$ or $-b(-')$, and neutral nouns end in $-o(-\mathrm{o}),-e(-\mathrm{e})$, or $-e \cdot(-\mathrm{e})$. The number in Russian morphology has two types, единственное число (edinstvennoe čislo) 'singular' and множественное число (mnoźestvennoe čislo) 'plural'. In the nominative case, plural masculine nouns end in $-b l / u(-y / i)$, feminine nouns in $b l / u$ $\mathrm{y} / \mathrm{i})$, and neutral in $-a / g(-\mathrm{a} / \mathrm{ja})$.

Savko (2004, pp. 186-187) explains and categorizes morphological cases in the Russian language into:

1. именителный падеж (imenitel'nyj padeź) 'nominative', which answers the questions kmo? (kto?) 'who' and ymo? (čto?) 'what'

2. родительный падеж (roditel'nyj padeź) 'genitive', which answers the questions кого? (kogo?) 'from who' and yezo? (čego?) 'from what'

3. дательный падеж (datel'nyj padeź) 'dative', which answers the questions кому? (komu?) 'to whom' and чему? (čemy?) 'to what'

4. винительныцй падеж (vinitelnyj padeź) 'accusative', which answers the questions кого? (kogo?) who' and чего? (čego?) 'what'

5. творительньій падеж (tvoritel'nyj padeź) 'instrumental', which answers the questions кем? (kem?) 'with whom' and чем? (čem?) 'with what'

6. предложный падеж (predloźnyj padeź) 'prepositional', which answers the questions о ком? (о kom?) 'about whom' and о чем? (о čem?) 'about what'

In the Russian language, prepositions are closely related to nouns. The most frequently used prepositions are $\kappa(\mathrm{k})$, в/ на (v/ha), which signify movements, and $c(\mathrm{~s})$, which signifies instrumental case (Savko, 2004, pp. 390-395).

Nouns can also be compound nouns, and their orthography is the combination of words to form compound nouns. There are elements that form compound words, prefixes or suffixes. One of the prefixes to form compound nouns is cynep- (super) 'super-' (Rozental', 2005, pp. 43). An example of a compound noun using the prefix cynep- (super-) 'super-' is the word суперобложка (superobloźka) 'super layer.' One of the suffixes to form compound nouns is -метр (-metr) 'meter' (Rozental', 2005, pp. 44). An example of a compound noun using the suffix -меmp (-metr) 'meter' is the word ваккууметр (vakkuumetr) 'vacuum meter,' динамометр (dinamometr) 'dynamometer', and милливольтметр (millivolt'metr) 'mini voltmeter'.

This research discusses the Russian syntax of nouns, which includes the position of nouns in sentences, especially the subjects as the primary part of a sentence (Popov, 1986: 296308) and secondary parts such as the objects and other complements (Popov, 1986, pp. 322-333).

\section{METHOD}

The descriptive-analytical method was used in this research. According to Sugiyono (2008, p. 105), this method is done by collecting naturally occurring data and then processing and analyzing the data in order to explain the phenomenon. This research classifies loan nouns in the automotive context and analyzes their positions in sentences in light of the previously discussed theories. The data collected in this research is from a Russian automotive magazine Motoekspert December 2017 edition. The loan nouns were noted and coded based on the page where they were found. For example, a code (M, 15) means the loan noun was found in the magazine, Motoekspert Desember 2017 edition, on page 15. Conclusion was drawn based on the analysis.

\section{RESULT AND DisCUSSION}

The discussion on morphosyntax of the Russian language is based on the aforementioned theories. The discussion covers the context (automotive), types of words (loanwords), word class in the Russian language (nouns), noun criteria in the Russian language (gender, number, and case), and position in the sentence.

\section{A. Loan nouns in the automotive context with nominative case}

The word uaccu (šassi) 'chassis' means "the steel frame, wheels, engine, and mechanical parts of a motor vehicle, to which the body is attached." This word comes from the French word, châssis (Novejšij Slovar' Inostrannyx Slov i Vyraźenij, 2001, p. 908).

\section{"Двигатель и шасси проектировались совместно." $(\mathrm{M}, 14)$ \\ (dvigatel' i šassi proektirovalis' sovmestno) \\ 'Engine and chassis were simultaneously designed.'}

In the above sentence, the word maccu (̌̌assi) 'chassis' is a loan noun belonging to the neutral, singular noun category with nominative case. The word maсcu (sassi) 'chassis' in that sentence is the subject of the sentence.

\section{B. Loan nouns in the automotive context with genitive case}

The word супербайк (superbajk) 'superbike' means "a high-performance motorcycle." This word is a compound noun consisting of the prefix cynep- (super-) 'super-' (Rozental', 2005, p. 43) and the loan word 'bike' from the English language.

(http://www.dictionary.com/browse/bike?s=t) 
"Наконец-то японцы стали использовать задние покрышки размерностью 190/55-17 не только на версиях

SP своих литровых супербайков, но и на нейкедах." (M, 27)

(nakonec-to japoncy stali ispol'zovat' zadnie pokryški pazmernost'ju 190/55-17 ne tol'ko na versijax SP svoix litrovyx superbajkov, no i na nejkedax)

'Finally the Japanese (engineers) use rear wheels of 190/55-17 not only for (motorbike) SP superbike series (with) one liter engine, but also for naked (motorbike).'

In the sentence above, the word cynepбайк (superbajk) 'superbike' is a loan noun belonging to the masculine noun category with genitive case, so the plural form is declined into супербайков (superbajkov). The word супербайк (superbajk) 'superbike' in that sentence is an adjective of the noun версиях (versijax) 'versions' that acts as a complement of the sentence.

\section{Loan nouns in the automotive context with dative case}

The word скутер (skuter) 'scooter' means "a small light motorcycle which has a low seat." This word comes from the English word 'scooter' (Novejšij Slovar' Inostrannyx Slov i Vyraźenij, 2001, p. 746).

"Премиальность марки BMW несёт в применении к скутеру С 400 Х плохую службу - его хочется сравнить с более серьёзными в техническом плане противниками muna T - Max $u$ Burgman." (M, 20)

(premial'nost' marki BMW nesjot $\mathrm{v}$ primenenii $\mathrm{k}$ skuteru $\mathrm{C}$ 400 X ploxuju sluźbu - ego xočetsja sravnit' s bolee ser'joznymi v texničeskom plane potivnikami tipa T - Max i Burgman)

'The premium brand BMW gives a challenging task to scooter $\mathrm{C} 400 \mathrm{X}$-it is expected to compare with its more technically serious competitors such as type $\mathrm{T}-\mathrm{Max}$ and Burgman.'

In the sentence above, the word cкymep (skuter) 'scooter' is a loan noun belonging to the masculine, singular noun category with dative case, so it is declined into скутеру (skuteru). The word скутер (skuter) 'scooter' in that sentence acts as an indirect object. The preposition $\kappa(\mathrm{k})$ signifies object movement.

\section{Loan nouns in the automotive context with accusative case}

The word модификаиия (modifikacija) 'modification' means "the act of modifying or the condition of being modified." This word comes from the Latin word modificatio (Novejšij Slovar' Inostrannyx Slov i Vyraźenij, 2001, p. 536).

"Но уже через два года она серьёзно обновилась, $а$ также раздвоилась, получила новую модификацию Africa Twin Adventure Sports." (M, 27) (no uźe dva goda ona ser'jozno obnovilas', a takźe razdvoilas', polučila novuju modifikaciju Africa Twin Adventure Sports)

"But after two years it (Honda) had made effort to renew and launch, until the new modification of Africa Twin Adventure Sports arrived .’

In the above sentence, the word модификация (modifikacija) 'modification' is a loan noun belonging to the feminine, singular noun category with accusative case, so it is declined into модификацию (modifikaciju). The word модификация (modifikacija) 'modification' is a direct object in the sentence.

\section{E. Loan nouns in the automotive context with instrumental case}

The word мотор (motor) 'motor' means "the part in a machine, vehicle, or boat that uses electricity or fuel to produce movement, so that the machine, vehicle, or boat can work." This word comes from the Latin word motor (Novejšij Slovar' Inostrannyx Slov i Vyraźenij, 2001, p. 545).

\section{"Многие спортсмены гоняют на R6 со стандартном мотором." (M, 46) \\ (mnogie sportsmeny gonjajut na R6 so standartnom motorom) \\ 'Many racers use R6 with standard motor.'}

In the sentence above, the word мотор (motop) 'motor' is a loan noun belonging to the masculine, singular noun category, so it is declined into мотором (motorom). The word мотор (motop) 'motor' in that sentence is a complement. The preposition $c(\mathrm{~s})$ signifies instrumental case.

\section{F. Loan nouns in the automotive context with prepositional case}

The word спидометр (spidometr) 'speedometer' means "a device fitted to a vehicle to measure and display the speed of travel." This word is a compound noun consisting of a loan word from the English language, 'speed' (http://www.dictionary.com/browse/speed?s=t) and a suffix метр (-metr) '-meter' (Rozental', 2005, p. 44).

\section{"На КТМ мне удалось достичь на спидометре циифрь $150, \ldots "(\mathrm{M}, 37)$}

(na KTM mne udalos' dostič' na spidometre cifri 150)

'On KTM I maintained (speed) to achieve 150 on speedometer ...'

In the sentence above, the word спидометр (spidometr) 'speedometer' is a loan noun belonging to the masculine, singular noun category with prepositional case, so it is declined into спидометре (spidometre). This word is the complement in the sentence. The preposition в/на (v/ha) signifies object movement. 


\section{V.CONCLUSION}

The research findings show that loanwords in the Russian language come from various foreign languages. The spelling of these loanwords follows the orthographic rules in the Russian language. In terms of sentence structure, these loan nouns follow the rules of nouns in the Russian language in that they have a certain gender, number, case and position in the sentence. Compound nouns were also found in the magazine.

\section{References}

Hudson, RA. Ed. (1969). Encyclopedia of Linguistic. Cambridge: Cambridge University Press.

Kushartanti, Yuwono, \& Lauder (2009). Pesona bahasa: langkah awal memahami lingusitik. Jakarta: PT Gramedia.

Popov, R. N. (1986). Sovremennyj russkyj jazyk. Moskva: Proveščnie.

Rozental', D. E. (2001). Sovremennyj russkyj jazyk. Moskva: Ajris Press.

Rozental', D. E. (2005). Spravocnik po pravopisaniju $i$ literaturnoj pravke. Moskva: Ajris Press.

Savko, I. E. (2005). Russkyj jazyk. Minsk: Harvest.

Sugiyono (2008). Metode penelitian kuantitatif kualitatif dan $R \& D$. Bandung: Alfabeta.

Darheni, N. (2009). Penyerapan leksikon asing dalam bidang otomotif ke dalam bahasa Indonesia: tinjauan secara morfologis dan fonologis. Jurnal Sosioteknologi Edisi 17 Tahun 8, Agustus 2009.
Motoekspert No. 12 (104) December 2017. Moskva: OOO Motopressa.

Novejšij Slovar' Inostrannyx Slov i Vyraźenij. (2001). Minsk: Xarvest.

Oźegov, S. I. (2015). Tolkovyj slovar' russkogo jazyka. Moskva: Mir i Obrazovanie.

Haugen, E. (1950). The analysis of linguistic borrowing. Linguistic Society of America, 26(2), 210-231. Retrieved from http://www.jstor.org/stable/410058

Chassis. (n.d.). In Collins dictionary online. Retrieved from https://www.collinsdictionary.com/dictionary/english/cha $\underline{\text { ssis }}$

Modification. (n.d.). In Collins dictionary online. Retrieved from

https://www.collinsdictionary.com/dictionary/english/mo dification

Motor. (n.d.). In Collins dictionary online. Retrieved from https://www.collinsdictionary.com/dictionary/english/mo tor

Motorcycle. (n.d.). In Collins dictionary online. Retrieved from

https://www.collinsdictionary.com/dictionary/english/mo torcycle

Scooter. (n.d.). In Collins dictionary online. Retrieved from https://www.collinsdictionary.com/dictionary/english/sco oter

Speedometer. (n.d.). In Collins dictionary online. Retrieved from

https://www.collinsdictionary.com/dictionary/english/spe edometer

Superbike. (n.d.). In Collins dictionary online. Retrieved from https://www.collinsdictionary.com/dictionary/english/sup $\underline{\text { erbike }}$ 